\title{
CUURRENT TOPICS.
}

University of Glasgow-Commemoration Day - On 18th April Commernoration Day was observed at Glasgow University for the second time in its history. This new feature was introduced into the academic life of the city two years ago, and the intention is that it should be repeated biennially. Its main objects are to cómmemorate the great names associated with the ancient seat of learning and to stimulate the interest of graduates in their Alma Mater. The arrangements, which were in the hands of a joint committee of the Court, Senate, and General Council, embraced a religious service, a discourse on Francis Hutcheson. (who was Professor of Moral Philosophy in the College from 1730 to 1746), by the I present occupant of that Chair, Mr. Henry Jones, LL.D., D.Litt., F.B.A., and the conferring of the degrees of D.D. and LL.D. Later in the day a portrait of the Principal, by Sir George Reid, was presented to the University. The proceedings concluded with a dinner in the evening. A new feature of the dinner was the presence of a large number of ladies, not in the gallery, as on former occasions, but at the tables. Each gúest received a copy, in pamphlet form, of Professor Jones's oration on Francis Hutcheson ; and it would be difficult to conceive a more fitting memento of this second Commemoration Day.

Royal Infirmari Appointements-Drs. Norman Macnair and John Henderson have been appointed Dispensary Physicians in room of Drs. Scott and Hunter. Drs. John A. C. Macewen, A. Gálbraith Faulds, and Thomas Kay have been appointed Dispensary Surgeons in room of Drs. Bewar, Rutherfurd, and Paterson.

Scotitish Association of Medical Women.-The inaugural meeting of the Scottish Association of Medical Women was beld last month in Minto House, Chambers Street, Edinburgh. The object of the Association is to have an organisation which can deal with questions of importance to médical wonen. Dr. Emily Thomson, Dundee, presided, and the meeting was largely attended. 
"Poisonous ShortbreaD."-Quite a furore has been created, among master bakers particularly, by the evidence of Professor Thorpe, given recently before a Select Committee of the House of Commons, when he referred to some cases of poisonous material in shortbread made in Glasgow. Glasgow bakers have a very extensive trade in this commodity, and steps were immediately taken to obtain an explanation from Professor Thorpe, in order to set the trade right in the eyes of the public. The following letter was addressed to the Secretary - of the Glasgow Division of the Scottish Association 'of Master Bakers :-

\section{Government House Laboratory, \\ Clement's Inn Passage, Stkand, Londòn, W.C., 9th April, 1906.}

DeÁr Sir,-The paragraph you send me is "a very incomplete summary of my evidence before the Select Committee on the butter trade. The reference to the shortbread was in answer to questións relative to the use of colouring matter in food, and was given, with others, as an example of the evils attending the uncontroHed employment of such substances in connection with the preparation of food.

The incident occurred towards the end of December, 1871, at which time I occupied the Chair of Chemistry in Anderson's College, and reports relating to it appeared in the Glasgow and in one or two of the London newspapers at the time. - Yours faithfully, .

\section{T. S. THORPE.}

Jjames M. Camṕbelt, Esq.,

147, George Street, Glasgow.

Small-pox, among Alien Emigrants in Glasgow.-The necessity for some system of inspection of alien emigrants passing through the city is evidenced by a report presented to the Town Council by Dr. A. K. Chalners; Nedical Officer of Health. The report states that on the evening of 26th March, a Russian Jew was admitted to hospital suffering from small, pox. He had arrived from Russia, via Rotterdam and Grangemouth, on 22nd March, and, with four others, had been accommodated in one of the hotels in the city. On the evening of his admission he had visited the shop of a fellow-countryman, who, observing an eruption on his face, took him to another hotel which is also used by, emigrants, and at once communicated with the medical officer of the shipping compary concerned. In this latter hotel the patient was detained in a room by himself; but in the hotel where he lived he had occupied two rooms in succession, and only his lack of English. 
appears to have prevented him mixing with the other inmates. In all, between 400 and 500 persons were here accommodated, a small number of whom were foreigners, and, like the patient, awaiting their despatch to America. Every week at present a considerable number of emigrants come to Glasgow, and are detained for a time, en route to America. During their stay they are housed in several places, some of which are used entirely for the purpose; but there are besides, thirteen private houses registered as lodging-houses, which accomodate the overflow from the hotels as occasion requires. The Aliens Act, 1905, holds the shipping companies responsible for the completion of transit of such persons as they have introduced into this country; but while in Glasgow, as the above-mentioned case shows, such persons may infect a considerable section of the resident population. It would seem desirable, so long as this traffic continues, that these emigrants should be housed by themselves and regularly inspected. It is worthy of note also that there is no daily medical inspection of emigrants, although the interpreters employed are expected to intimate at once any case of sickness coming under their notice. In the present case this system failed.

Infantile Mortality Question at Barrhead.-The Town Council of Barrhead have for a long time had under consideration the high death-rate among infants in the burgh. Dr. Corbett, the medical officer, reports that the deaths are due in great part to carelessness and ignorance in feeding and protecting young children, and, on his suggestion, the Council have agreed to appoint a qualified nurse to assist in the proper methods of feeding, cleaning, and clothing young children.

Registrar-General's Returns. - The report of the Registrar-General for Scotland for 1905 has just been issued. The population in the middle of the year is set down in the estimate as $4,676,603$. The births registered amount to 131,381 , being 1,189 fewer than in the preceding year, and 1,010 fewer than the mean of the previous five years. The diminution is general and not limited to any particular districts. The birth-rate of 28.093 per 1,000 of the population is the lowest yet recorded for Scotland since the commencement of the reports. As regards towns, the highest birth-rate is in Greenock, 30.5; while Glasgow is a good second with 30 , and Edinburgh is lowest with 23.

The deaths registered in Scotland number 74,526, which is 3,435 fewer than in 1904. The death-rate for the year, per 
1,000 of the population, is 15.936 . This is the lowest deathrate recorded since the office was established. The decline in the rate is more marked in the large towns. Greenock has the highest with 18.8 and Leith the lowest with 13.9 , Glasgow coming third with $17 \cdot 9$, and Dundee having a rate of 18 .

\section{NEW PREPARATIONS, \&C.}

\section{Pleated Compressed Sanitary Towels ("Tabloid"} BRAND).-Messrs. Burroughs Wellcome \& Co. send samples of the above, which possess all the characteristics of the very best sanitary towels. After being highly compressed, each is enclosed in an efficient protective covering, perfect cleanliness being thus secured. The incredibly small space which they occupy is of great advantage, and renders them particularly convenient when travelling. Four sizes are issued. Each size is made up in packages of one dozen.

Wellcome's Photographic Exposure Record and Diary, 1906 (London: Burroughs Wellcome \& Co.).-The 1906 edition of this diary retains the leading features of its predecessors, but has been subjected to a thorough revision. Attention is drawn to the list of British, Continental, and American plates and films, giving the speeds to be used with the exposure calculator. Monthly light tables are provided, and a mechanical calculator is fixed to the inside of the back cover. Prizes are offered for photographs produced with Tabloid photographic chemicals.

A Guide to Diabetic Cookery (London: Published by Callard \& Co.).-This is an interesting and useful guide, which we gladly commend to the medical profession as well as to those of the laity who have the misfortune to be interested in diabetes. The author remarks that a considerable advance in the production of carbohydrate-free foods has taken place in recent years, and that further improvement is sure to be effected. It is greatly to be wished that some of these foods were obtainable at less cost than now. We are told here that "the processes by which gluten flour is produced are difficult and wasteful, and it cannot be sold for less than $2 \mathrm{~s}$. per pound."

Bipsine Bread (Edinburgh: Bipsine Food Co., 39 Royal 